\title{
XVI. On the mode of manufacturing salt by evaporation on faggots
}

\section{R. Bakewell Esq.}

To cite this article: R. Bakewell Esq. (1824) XVI. On the mode of manufacturing salt by evaporation on faggots, Philosophical Magazine Series 1, 63:310, 86-92, DOI: $10.1080 / 14786442408644472$

To link to this article: http://dx.doi.org/10.1080/14786442408644472

里 Published online: 29 Jul 2009.

Submit your article to this journal

Џ Article views: 2

Q View related articles $\sqsubset$ 


\section{On the Mode of manufacturing Salt by Evaporation on Faggots. By R. BakewelL, Esq.*}

$\mathbf{T}$

HE salt-works at Montiers in the Tarentaise are particularly deserving attention, being perhaps the best conducted of any in Europe with respect to economy. Nearly three million pounds of salts $\uparrow$ are extracted annually from a source of water which would scarcely be noticed, except for medical purposes, in any other country.

The springs that supply the salt-works at Montiers rise at the bottom of a nearly perpendicular rock of limestone, on the south side of a deep valley or gorge through which the Doron runs before it joins the Isere. The distance of the salt-works from the spring is about a mile; the water runs in an open canal, but is received in a reservoir, where it deposits part of its ochreous contents. The water rises from the rock with considerable force, and emits much gas, which is principally carbonic with a mixture of sulphuretted hydrogen; it has an acidulous and slightly saline taste. The temperature of the strongest spring is $99^{\circ}$ Fahrenheit; it contains 1.83 per cent. of saline matter. The second spring has the temperature of $95^{\circ}$, and contains 1.75 of saline matter. Besides common salt, the water contains in small proportions sulphate of lime, sulphate of soda, and sulphate and muriate of magnesia; together with oxide of iron. During the great earthquake that destroyed Lisbon in 1756, the salines at Montiers ceased te flow for forty-eight hours; and when they flowed again, their quantity was increased, but the saline impregnation was weakerf. It may seem extraordinary that the waters at Montiers, which have only half the strength of sea water, should repay the expense of evaporation; but the process by which it is effected is both simple and ingenious, and might be introduced with great advantage on many parts of our own coast, should the salt duty be entirely removed. The salt-works at Bex in the Pays de Vaud are nearly similar to those at Montiers, but not on so extensive a scale, and a very useful part of the process at Montiers is not adopted at Bex.

* Extracted from volume i. of " Travels in the Tarentaise, and varions Parts of the Grecian and Pennine Alps, and in Switzerland and Auvergne, in the Years 1820,1821 , and $1822 . "$ In 2 vols. octavo.

+ In this quantity are comprised common salt, Glauber's salt, and the alkaline salts sold to the glass manufacturers.

I The geological position of these springs, and the numerous thermal waters of the central chasm of the Alps, are described in the latter part of the volume. 
I shall endeavour to give such a description of the process as will enable any person to imitate it in this country; indeed so little is known of this mode of evaporation by faggots, that it has been often stated by English writers, and has recently been gravely repeated, that it consists in throwing salt water upon burning faggots, and gathering the salt that remained! This would be a mode of making salt as wise and practicable as the nursery method of catching birds by putting salt on their tails. It is obvious that water so weakly impregnated with salt as to contain only one pound and a half in every thirteen gallons, could not repay the expense of evaporation by fuel in any country. The water of the North Sea contains $2 \frac{1}{4}$ per cent. of salt ; and yet it has never been attempted, I believe, to make salt from it with coal fires, even on the coast of Northumberland or Durham, where refuse coal suited to the purpose might be purchased for $1 \mathrm{~s} .6 d$. per ton.

The first attempt at Montiers, in 1550, to make salt by atmospheric evaporation, was by arranging pyramids of rye straw in open galleries, and letting the water trickle through gradually and repeatedly. By this process a portion of the sulphate of lime was deposited on the straw, and the water became concentrated to a certain degree. It was then carried to the boiler and further evaporated by fuel. In 1739 the present buildings were erected by order of Charles Emanuel the Third.

There are four evaporating houses, called Maisons d'Epines (literally, houses of thorns). Nos. 1 and 2 receive the water from the reservoir, and concentrate it to about three degrees of strength, viz. they evaporate one-half of the water they receive. These houses of evaporation are 350 yards in length each, about 25 feet in height, and seven feet wide. They are uncovered at the top. 'They consist of a frame of wood, composed of upright posts, two and a half feet from each other, ranging on each side, and strengthened by bars across; the whole is supported on stone buttresses, about three feet from the ground, under which are the troughs for the salt water to fall into. The frame is filled with double rows of faggots of black thorn, ranged from one end to the other, up to the top; they are placed loosely, so as to admit the air, and supported firmly in their position by transverse pieces of wood. In the middle of each Maison d'Epines is a stone building, containing the hydraulic machine for pumping the water to the top of the building; it is moved by a water-wheel. When the water is raised to the top, it is received in channels on each side, which extend the whole length of the building; from these 
long channels it is made to pass into smaller ones by the side, from which it trickles through a multitude of small holes, like a very gentle shower, upon the faggots, where it is divided into an infinite number of drops, falling from one point to another. Being thus exposed to the contact of the air, it gains one degree of strength in falling, and, by the action of the pumps, it is raised again, and falls in other showers, till it has acquired the strength required for passing to the evaporating house, No. 3.

The process is conducted with less nicety in Nos. 1 and 2 than in the others, and, as I mentioned before, the houses are not covered. The pumps moved by the machine in the centre of the building, are distributed at equal distances on each side of the Maison d'Epines. The water is not always let to trickle down on both sides of the thorns, but only on that exposed to the wind. The two buildings, Nos. 1 and 2, are placed at different angles, to catch the different currents of wind that rush down the valley. No. 3 is constructed on the same principles as Nos. 1 and 2 ; it receives the water from them both ; it is $\mathbf{3 7 0}$ yards long, and is covered, to preserve the salt water from the rain. There are twelve pumps on each side in this building, and more care is taken to distribute the water equally; here it is concentrated to the strength of twelve per cent., and deposits most of its remaining sulphate of lime, in incrustations on the twigs.

The water being now reduced to about one-seventh of the original quantity, and raised to the strength of twelve degrees, is passed along channels to the Maison d'Epines, No. 4. This is only seventy yards in length : here it is further concentrated by a similar process, till it nearly reaches the point of saturation, but this depends on the season. In dry weather, it is raised to twenty-two degrees; but in rainy, moist weather, to eighteen degrees only. In sunmer-time the whole process of evaporation, in passing through the different houses, is about one month ; in wet seasons it is longer. The stream of water that sets in motion the hydraulic machines for raising the saline water to the top of the buildings, is brought by a small aqueduct from the river Doron. When once in motion, the process goes on and requires little further attention, or manual labour, till it is completed. When the water is nearly saturated, it passes to a large building, where are the pans for boiling, and the salt is crystallized in the usual method. That the reader may form an idea of the quantity of water evaporated before it comes to the pans, I will state the reduction at each of the evaporating houses: 
by Evaporation on Faggots.

8000 hogsheads, when received at Nos. 1 and 2, con-

tain about $1 \frac{1}{2}$ per cent of salt . reduced to

4000 hogsheads, when received at No. 3, contain

about 3 per cent. of salt . . . . reduced to 1000

10 vo hogsheads, when received at No. 4, contain

about 12 per cent. of salt . . . . reduced to

hogsh.

4000

550

550 hogsheads, received at the pans, contain near

22 per cent. of salt.

Thus, out of every 8000 hogsheads, passing through the Maisons d'Epines, 7450 are evaporated by the air in summer, and about 7000 in winter; and only one-sixteenth part of the fuel is consumed, that would be required for evaporating the whole quantity of water by fire.

The faggots are changed at periods of from four to seven years. Those in Nos. 1 and 2, where the saline impregnation is weak, will decay sooner than in Nos. 3 and 4 . In No. 3 all the twigs acquire so thick a coating of selenite, that when broken off, they resemble stems and branches of encrinites.

The Maison de Cordes was invented by an ingenious Savoyard named Buttel. It is forty yards in length and eleven wide: it is much stronger than the Maison d'Epines, the roof being supported by six arches of stone work; the intermediate spaces on the sides being left open. In every one of these divisions are twelve hundred cords, in rows of twenty-four each, suspended from the roof, and fixed tight at bottom. The cords are about sixteen feet in length. The water is raised to a reservoir at the top of the building, and distributed into a number of small transverse canals, each row of twentyfour cords having one of these canals over it, which is so pierced as to admit the water to trickle down each separate cord, drop by drop. The original intention of this building was to crystallize the salt itself upon the cords, for which purpose the water was made use of from the pans after it had deposited a quantity of salt in the first boiling, to save the expense of fuel in a second boiling; the residue-water of the first boiling, by repeatedly passing over the cords, deposited all its salt in about forty-five days, and the cords were incrusted with a cylinder of pure salt, which was broken off by a particular instrument for the purpose*. This process is at present abandoned for crystallizing; but the cords are still used for evaporating, and are found to answer better for the higher concentration of the water than the faggots. This method did not answer for the first evaporation, because the water rotted the cords; but it was discovered that the cords

* This process might be used for sea-water with particular advantage in warm cliniates, and the necesssity for boiling altogether avoided.

Vol. 63. No. 310. Feb. 1824. 
were not soon injured by it when it had acquired five degrees of strength. The cords, we were informed, had many of them remained thirty years in use without being changed: indeed, they were so thickly encased with depositions of selenite, that they were defended from the action of the water. This mode of evaporating is found to be more expeditious than that of the faggots.

A sketch of the evaporating-house No. 1 is annexed; No. 2 is similar to it in every respect.

In the covered house No. 3 there are twenty-four pumps, twelve on each side, to distribute the water more equally over the whole. This system of pumps is worked by joined bars of wood, which move backwards and forwards, and are connected by crank wheels with each piston, to raise and depress it. As I have before mentioned, they take care to evaporate on the windward side of the building. When I was on the top of No. 3, though the air was very warm, I felt an intense degree of cold, the consequence of speedy evaporation.

In the Maison de Cordes, it is found that the evaporation goes on more speedily in windy weather than in the Maisons d'Epines, as might be expected from the more ready access of air to the surface of the water. The cords are double, passing over horizontal rods of wood at the top and the bottom, to keep them firm in their positions, and at regular distances from each other. I did not see the cords without their envelope of selenite; but I was informed that they were not thicker than the finger. With the incrustations they were become as thick as the wrist.

Near the salt-springs there are the remains of a large reservoir, into which the water was formerly made to fall from a considerable height by a machine; but this mode of evaporation was only found to answer in very hot weather, and the process is given up.

The saline water is received into reservoirs from the springs, where it remains some time before it passes to the Maisons d'Epines, and here it deposits a considerable quantity, or nearly all, of its ferruginous matter: the canal along which it runs to the reservoirs is also lined with a red ocherous incrustation.

The total length of the Maisons d'Epines is as under:

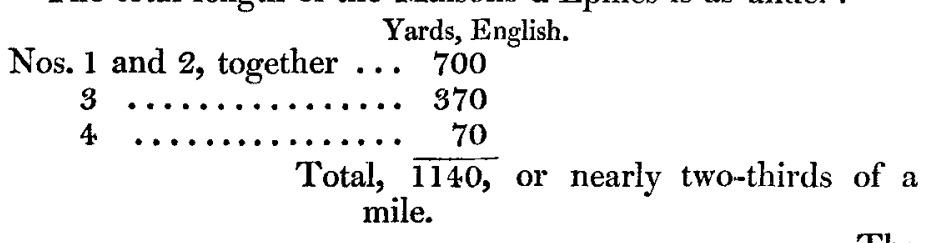




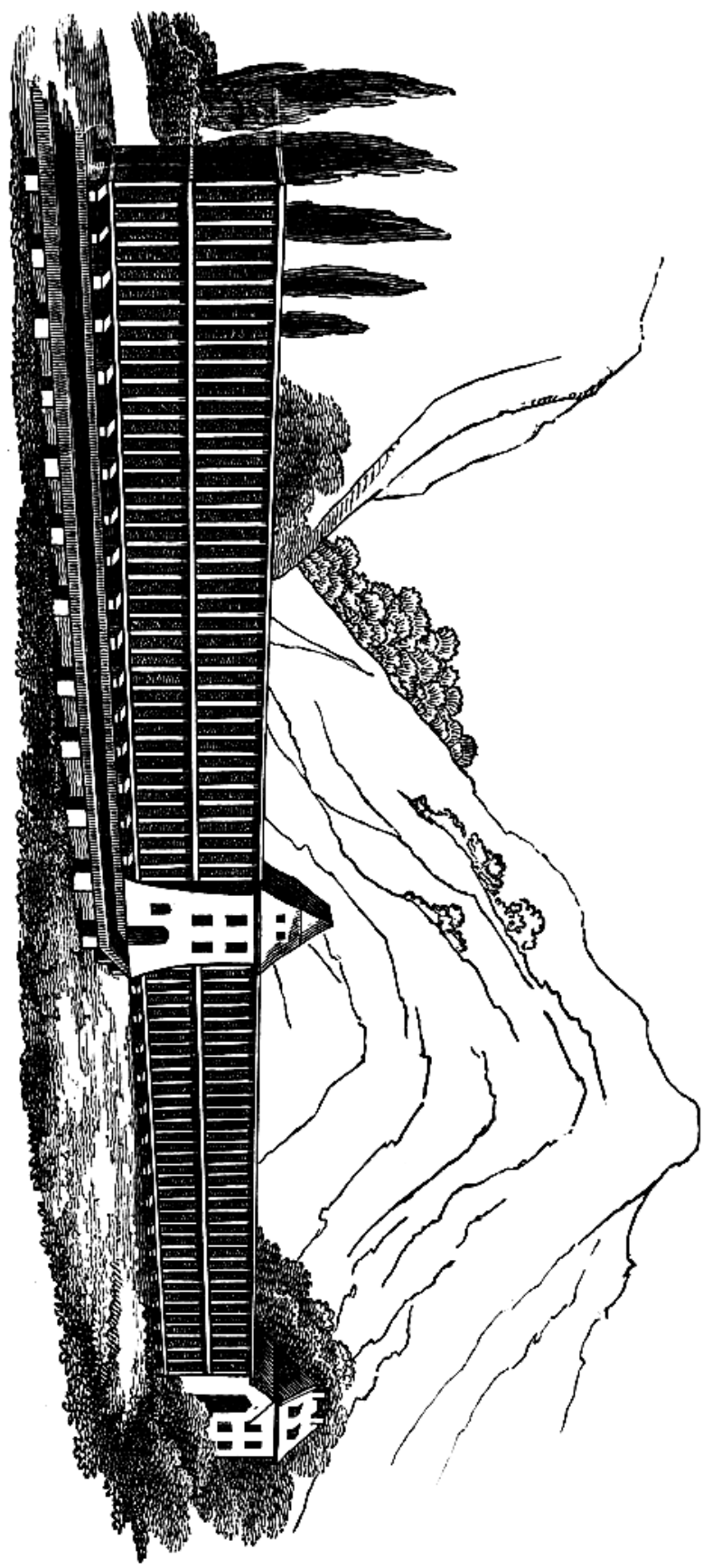


The fuel used at the pans for the last process is partly wood, and partly anthracite from the neighbouring mountains. The anthracite answers remarkably well when once ignited, as it preserves for a long time a regular degree of heat. The consumption of wood was formerly so great that it has denuded many of the higher mountains in the Tarentaise, and exposed them to the action of the atmosphere, which has occasioned vast eboulements; for it is found that forests are of the greatest utility, in preserving precipitous mountains from destruction. The fact is now so well ascertained, that the Government, for this cause alone, has lately paid particular attention to the preservation of the wood. The quantity of salt made here annually, is estimated at 100,000 myriagrammes, or about 2,250,000 lbs. avoirdupois, and about 9000 myriagrammes of sulphate of soda, or about $187,000 \mathrm{lbs}$. The other alkaline matter which adheres to the pans is sold to the glass-makers. The Government receives, on the average, 150,000 francs for the products, out of which it is estimated that 30,000 are expended for wood and fuel, 8000 for materials employed in the buildings, and for the faggots \&c., and 62,000 for the wages and the salaries of the different officers, leaving an annual profit of 50,000 francs. In some of the mountains of the Tarentaise, the gypsum is intermixed with rock salt en masse, and was worked by the peasants; but the places are now closed up, and so strictly guarded by order of the Government, that I found it difficult to procure specimens.

These mines were formerly worked, the salt being separated from the gypsum by solution, and subsequently evaporated by fire; but the great cboulements, caused by clearing away the wood from the sides of the mountains, obliged the Government to abandon the mines, and undertake the manufacture of salt at the Salines. These mines are mentioned by the Roman historians.

XVII. Description of a Pressure Gauge recommended for its Simplicity of Construction and Principle; with Observations on the Gauge proposed by Mr. Seaward *. By Mr. Henry RUSSELL.

\section{To the Editors of the Philosophical Magazine and Journal.}

Gentlemen,

A $\mathrm{N}$ examination of the instrument proposed by $\mathrm{Mr}$. Seaward, and described by him in your Magazine, No. 309, at pages 36 and following, has induced me to lay before your

* See p. 36 of this volume. 